\title{
Financial Sector Reforms in Nigeria: Issues and Challenges
}

\author{
Kanayo Ogujiuba \\ African Institute for Applied Economics, Enugu State, Nigeria \\ E-mail: kannyog@yahoo.com \\ Michael Emeka Obiechina \\ Liquidity Forecasting Office, Monetary Policy Department \\ Central Bank of Nigeria, Abuja, Nigeria \\ E-mail: emmyobiechina@yahoo.com
}

Received: August 18, 2010 Accepted: November 22, 2010 doi:10.5539/ijbm.v6n6p222

\begin{abstract}
One of the most challenging debates of modern history is whether financial development causes economic growth or a consequence of economic activity. There are on-going reforms in the sector in Nigeria, thus the importance of a review of the various reforms. Evidence as to whether and how reforms are remedying the traditional weaknesses of the Financial Sector is so far limited in Nigeria. Ongoing reforms to improve banks' corporate governance and internal systems suggest that the prospects for the financial sector to perform profitably and prudently, while reducing volatility in the system exist. The paper adopts an empirical review approach for its analysis. Paper suggests therefore, that the present reforms be reviewed and sustained in an orderly manner, for appropriate channeling of resources for investment and productive purposes. Efforts should be concentrated on the linkages of the sector with macro accounts and where financial development appears to have been the weakest. Furthermore, advancement of the financial sector vis-à-vis instruments should be the primary focus for the authorities. A counterfactual feedback mechanism should also be integrated within the financial sector for an appropriate signaling for the economic productive base.
\end{abstract}

Keywords: Financial development, Economic growth, Indicator, Reforms and Nigeria

\section{Introduction}

In a developing economy, such as Nigeria, financial sector development has been accompanied by structural and institutional changes. Financial sector generally have long been recognized to play a crucial role in economic development of an economy. According to Mc-kinnon (1973) and Shaw, (1973), the financial sector could be a catalyst for economic growth. Nonetheless, the present link between the financial sector and the real sectors of the economy still remain very weak. To an extent, Nigeria's financial sector is a bit complex, but sophisticated in terms of breadth and depth (Note 1). However, relative to the size of the economy and the financial needs, the financial sector can be said to be underdeveloped and still faces enormous challenges. Commercial lending to SMEs are virtually in non-existence; prudential regulation and enforcement still lagging behind international best practice; banks are apparently undercapitalized, while their risk management, lending practices, and internal controls remain inadequate as well as the stock of non-performing loans, which is becoming very large.

Reforms to modernize and strengthen the financial sector have continued in recent years. The cleaning-up of the stock of non-performing loans is yet to be completed and considerable progress has been made in improving commercial banks' corporate governance structures and risk management systems. Also in the international financial system, substantial progress has been made during recent years in forging a consensus on the importance of strengthening the architecture of the international financial system. The international community, acting through various forums, has identified a number of priorities, including the need to enhance its own - and the markets'-ability to assess the strengths and vulnerabilities of financial systems, and to develop the analytical and procedural tools needed to perform this task (Emenuga, 1996).

With the collapse of the international oil market in the early 1980s, the Nigerian economy began to show signs of distress. The emerging problems culminated in the introduction of an economic stabilization policy package in 
1981. Since then, efforts to solve the country's economic problems led to the introduction of various rounds of budget-tightening austerity measures (1982 - 1985), structural adjustment programmes (1986), NEEDS agenda (2004) and the 7 Point Agenda (2007). Financial sector reforms in Nigeria have mainly been motivated by the financial repression paradigm amongst others (Note 2). According to the McKinnon-Shaw hypothesis, financial repression arises mainly when a country imposes ceilings on nominal deposit and lending interest rates at a low level relative to inflation. The resulting low or negative real interest rates discourage savings mobilization and the channeling of the mobilized savings through the financial system. While the low and negative interest rates facilitates government borrowing, they discourage saving and financial intermediation, leading to credit rationing by the banking system with negative impacts on the quantity and quality of investment and hence on economic growth (Mwega et al 1990).

Nonetheless, the global financial system has witnessed rapid growth and substantial structural change during the last ten years leading to globalization of financial markets. The integration of financial markets has accentuated the rapid flow of capital across borders as well as magnified the contagious effects of financial crisis with wide implications for transmission of financial policies on the domestic economy and internationally, which is evident in Nigeria's financial system. Consequently, the Nigerian financial sector has to be abreast with reforms that should be sustained in an orderly manner, for appropriate channeling of resources for investment and productive purposes.

\section{Review of Literature}

For more than two decades after independence, the Nigerian financial system was repressed, as evidenced by ceilings on interest rates and credit expansion, selective credit policies, high reserve requirements, and restriction on entry into the banking industry. This situation inhibited the functioning of the financial system and especially, constrained its ability to mobilize savings and facilitate productive investment (Sylvanus I. \& Abayomi A., 2001) (Note 3). It facilitates saving and the efficient allocation of these savings to investment. In the process, it plays an important role in reducing risks and in the transformation of maturities in the saving-investment nexus (Nissanke et al. 1995). Financial institutions lower the cost of investment when they evaluate, monitor and provide financial services to entrepreneurs. They promote productivity and growth through improved efficiency of intermediation, a rise in the marginal product of capital and or an increase in the savings rate (Montiel, 1994).

Over the years, researchers have developed a variety of economic theories to explain soundness in financial markets. While earlier researchers relied on movements in economic fundamentals as the origin of financial distress and crisis, recent studies have highlighted the role of the information available to, and the expectations of, investors in explaining the behavior of financial markets. A substantial body of empirical work on finance and growth assesses the impact of the operation of financial system on economic growth, whether the impact is economically large, and whether certain components of the financial system, e.g. banks and stock markets, play a particularly important role in fostering growth at certain stages of economic development.

Financial liberalization is one of the key pillars of reforms in most countries of Africa. A lot of work has been done on the relationship between financial deepening and economic performance. Many studies find a close link between financial deepening, productivity and economic growth and conclude that policies affecting the financial sector have substantial effects on the space and pattern of economic development (Goldsmith 1969; King and Levine 1993). For example, it is estimated that policies that would raise the M2/GDP ratio by $10 \%$ would increase the long-term per capita growth rate by $0.2-0.4 \%$ points (World Bank, 1994). Callier (1991), maintained that the performance of the financial sector in Sub-Saharan Africa has an important bearing on the overall economic performance because: (i) the region continues to be in economic crisis and the financial system is relatively underdeveloped compared to any other developing region; (ii) structural adjustment programs would require more reliance on the private sector and hence its financing; (iii) the debt crisis and reduction in external savings translates to the need to increase the mobilization of domestic savings for investment; (iv) reform is needed if the financial system is to overcome and avoid the problems of financial distress and restore confidence; and (v) the need for international competitiveness requires that the financial system be as adaptable and flexible as possible. It is postulated that the financial sectors in many African countries (i) are segmented, fragmented and dualistic; (ii) are mainly bank-based, with few NBFIs; (iii) serve the short end of the market; (iv) are heavily regulated, with much of their services geared towards servicing the public sector deficits, leading to a crowding-out of the private sector; and (v) they face limited competition or innovations, with many of them dominated by oligopolies (Soyibo, 1994).

Financial sector reforms have also included (a) reducing direct and indirect taxation of financial institutions through reserve requirements, mandatory credit ceilings and credit allocation guidelines; (b) reducing barriers to 
competition in the financial sector by scaling down government ownership through privatization; and facilitating entry into the sector by domestic and foreign firms; and (c) restructuring and liquidation of solvent banks (Inanga, 1995). Patrick (1966) postulated a bi-directional relationship between financial development and economic growth. Ever since, a large empirical literature has emerged testing the hypothesis (Levine 19970). Two trends thus emerged in this respect; testing the relationship between economic growth and financial development, adopting a single measure and testing the hypothesis on a number of countries and secondly examining the hypothesis on a number of countries using either cross section or panel data techniques (Erdal et. al 2007)

Researchers have argued that financial fragility should be addressed immediately as signs shown up. The classic explanation for financial fragility is given by Irving Fisher (1933). He argued that fragility is closely correlated with macroeconomic cycles, and highlights, in particular, debt liquidation. A downturn triggered by over-indebtedness in the real economy requires, at some point, liquidation of this debt in order to bring the economy back to equilibrium. Debt liquidation would result in a contraction of monetary liabilities and a slowdown of velocity. These changes have several economic implications-reductions in prices, output, and market confidence, and increases in bankruptcies and unemployment. According to Fisher, therefore, financial fragility is largely based on deterioration in economic fundamentals. Other theories highlight factors affecting depositor confidence in the financial sector. Diamond and Dybvig (1983) discussed the potential existence of multiple equilibria in financial equilibrium, and that the banking sector finds itself in "bank run" equilibrium. They assumed that these equilibria are a function of random events known to all agents. Therefore, a bank run occurs when agents have deposited funds into a bank at a time of low probability of a bank run, and then later observe negative events that increase their anticipation of a bank run.

Several studies of financial problems appeared in the wake of the Mexican crisis in 1994, and before the emergence of the Asian crisis in 1997. These studies investigated the vulnerability of financial institutions in the face of exogenous shocks. Financial intermediaries are generally highly leveraged, engage in maturity transformation, transactions in markets with asymmetric information, and are subject to moral hazard through explicit or implicit deposit insurance. Sources of financial fragility explored in the studies include a falling growth rate, deterioration in the balance of payments, high inflation, volatile exchange rates, surges in stock market activity and prices, credit booms, weakening performance of export sectors, and deterioration in the terms of trade. In addition, these studies highlight non-quantifiable indicators of financial fragility, such as deficient banking supervision, inadequate instruments of monetary control, overly generous deposit insurance, inadequacies in the operation of the legal system, overexposure in international financial markets, lack of adequate accounting standards and practices, insufficient financial disclosure, and perverse incentive structures. The Asian crisis has provoked a new wave of financial sector studies, which confirm that macroeconomic shocks to output, exports, prices and the terms of trade, asset price booms, and inappropriate monetary and exchange rate policies, all result in financial pressure and contribute to crises in financial systems that are inherently fragile (Obadan, 2004).

\section{Financial Sector Evolution, Reforms and Global Financial Crisis in Nigeria}

\subsection{Financial Sector Evolution}

In any economy, the financial sector is the hub of productive activity. It comprises of an impressive network of banks and other financial institutions and a wide range of financial instruments. In Nigeria, the financial system is made of financial institutions, such as banks, insurance companies, specialized banks, capital market, finance companies, discount houses, bureau de change, mortgage institutions, community banks, and the development finance institutions (DFIs), each covering a particular area of activity or activities (Mordi, 2004). It performs the core function of financial intermediation, adequate payment services as well as the fulcrum for monetary policy implementation.

The Nigerian financial system has undergone several evolutionary stages ever since the independence of the country; foundation phase, Expansion phase, Consolidation and Reform phase (Ibid.). The phases marked different epochs in the evolution of the financial system.

\section{i. Foundation Phase}

This phase focuses on the establishment of institutions and development of necessary legislative framework. The phase is approximately from 1950 to 1970 . During this period, the Central Bank of Nigeria (CBN), the apex regulatory authority in the Nigerian financial sector was established. The CBN derives its legal authority from the CBN Act No. 24 Of 1991 (Amended in 1997, 1998, and 1999) and the Banks and Other Financial Institutions Act (BOFIA) No. 25 of 1991 (Amended in 1997, 1998 and 1999) and presently the CBN Act 2007, which preceded the CBN Act of 1958 and Banking Act of 1969. 


\section{ii. Expansion Phase}

The expansion phase was directed at availing the public of banking activities and this was facilitated by the increase in network of branches. This involves the expansion of banks branches into the rural and semi areas. The phase also witnessed priority lending to some sector of the economy. This phase takes approximately from $1970-1985$.

\section{iii. Consolidation and Reform Phase}

The Structural Adjustment Programme (SAP), which started in 1986, marked an era in Nigeria's financial sector reform. The monetary authorities relaxed the control and liberalize the sector. There was a deregulation of the economy and many institutions were set-up to regulate the growing financial sector. For example, there was the establishment of Nigeria Deposit Insurance Corporation (NDIC) in 1988, the Security and Exchange Commission (SEC) though established by SEC Act of 1979 but was further strengthened by SED Act of 1989 and Investment and Securities Act No. 45 of 1999.

\subsection{Financial Sector Reforms}

A peculiar feature of the reform program in Nigeria is the associated inconsistency in policy implementation. The financial sector in Nigeria is dominated by the banking sector, especially the commercial banking. The deposit money banks (DMBs') accounts for 93.0 per cent of non-central assets in 2000 (World Bank, 2000) and 94.0 and 95.2 per cent of the aggregate financial savings in 2002 and 2003, respectively as well as above 60.0 per cent of the stock market capitalization (Note 4). Commercial banking started in 1892 with the establishment of the first banking firm, Standard Bank of Nigeria Ltd (now First Bank). Since then, the number of commercial banks has exploded. Thus, an understanding of the structural changes in the financial sector as a whole is of great importance to all stakeholders; as it would help in designing appropriate legislation to enhance competition. The Nigerian banking system has undergone remarkable changes over the years, in terms of the number of institutions, ownership structure, as well as depth and breadth of operations. These changes have been influenced largely by challenges posed by deregulation of the financial sector, globalization of operations, technological innovations and adoption of supervisory and prudential requirements that conform to international standards.

\subsubsection{Reforms}

At the commencement of comprehensive financial sector reform in Nigeria in 1987, the sector was highly repressed. Interest rate controls, selective credit expansion and use of reserve requirements and other direct monetary control instruments were archetypal characteristics of the financial system. Access into banking business was limited and government-owned banks dominated the industry. The reform of the foreign exchange market, which until then was also controlled, began in 1986. Indeed, the financial sector reform was a component of the comprehensive economic reforms programmed, Structural Adjustment Program (SAP), which was adopted in 1986.

Although the policy planks of SAP in Nigeria were the prototype prescriptions of the Bretton Woods institutions, the program was sold to Nigerians by government as Nigeria's alternative to IMF loan-based adjustment. The introduction of the program was on the heels of the rejection of IMF loan package with its conditionalities, a decision that reflected the consensus of a nationwide debate. The main financial sector reform policies applied were deregulation of interest rates, exchange rate and access into banking business. Other reform measures included, establishment of Nigeria Deposit Insurance Corporation (NDIC), strengthening the regulatory and supervisory institutions, upward review of capital market deregulation and introduction of indirect monetary policy instruments. Some distressed banks were liquidated while the Central Bank of Nigeria took over the management of others. Government share holdings in some banks were also sold to the private sector. The reform of the foreign exchange market in 1986 began with the dismantling of exchange controls and establishment of a market-based autonomous foreign exchange market. Bureaux de changes' were allowed to operate from 1988. However a fixed official exchange rate has continued to exist alongside the autonomous market.

In 1994, the gradual market-based depreciation in the official exchange rate was truncated by a sharp devaluation in a bid to close the widening gap between the official and the autonomous exchange rate. Unsatisfied with the observed further widening of the gap between the two exchange rates, government outlawed the autonomous foreign exchange market and reintroduced exchange controls in 1994. But after a full year of exchange controls, the autonomous market was brought back in 1995 to co-exist with the fixed official exchange rate. The continued operation of the official exchange rate brings with it a great deal of distortions in the domestic allocation of resources within the public sector. This is very pronounced in the vertical distribution of export 
earnings among the three levels of government. A similar pattern of policy reversals applies to the reform of interest rates. First introduced in 1987, the market-determined interest rates ruled until 1991 when interest rates were capped. But after only a year of controls, market forces were permitted once more to determine all interest rates in 1992 and 1993. While indirect monetary instruments (open market operations) have been initiated since 1993, some measures of controls such as sectoral credit allocation guidelines have continued to be applied. In the sphere of bank licensing and regulation, the reform was ushered in with deregulation of bank licensing in 1987. When the increase in the required banks paid up capital in 1989 and the reform of their accounting procedure (1990) appeared insufficient to curb the "excesses" of the sector, government placed total embargo on bank licensing in 1991 In Nigeria, the liberalization of interest rates and entry into banking business gave rise to sharp increases in nominal interest rates. With the additional effects of currency devaluation and higher Central bank-financed public sector deficits within the period, the rate of inflation soared.

However, despite the SAP Reforms, the seemingly lackluster performance of banks in lubricating the economy was the precursor to the emergence of widespread banking crisis in the early 1990s. The linkage between the sector and the growth of the economy remained weak throughout this period. Not only was industrial finance appalling, the cost of capital was prohibitive. The Nigerian banking system has undergone remarkable changes over the years, in terms of the number of institutions, ownership structure, as well as depth and breadth of operations. These changes have been influenced largely by challenges posed by deregulation of the financial sector, globalization of operations, technological innovations and adoption of supervisory and prudential requirements that conform to international standards.

\subsubsection{Reforms}

Prior to the reforms started in 2004, the Nigerian banking sector was still weak and fragmented, often financing short-term arbitrage projects rather than productive private investments. For clarity, we can summarize the major problems of many Nigerian banks as follows:

a) Weak corporate governance, evidenced by high turnover in the Board and management staff, inaccurate reporting and non-compliance with regulatory requirements, falling ethics and de-marketing of other banks in the industry;

b) Late or non-publication of annual accounts that obviates the impact of market discipline in ensuring banking soundness;

c) Gross insider abuses, resulting in huge non-performing insider related credits;

d) Insolvency, as evidenced by negative capital adequacy ratios and shareholders' funds that had been completely eroded by operating losses;

e) Weak capital base, even for those banks that have met the minimum capital requirement, which currently stands at N1.0 billion or US\$7.53 million for existing banks and N2.0 billion or US\$15.06 million for new banks, and compared with the RM2.0 billion or US\$526.4 million in Malaysia; and

f) Over-dependency on public sector deposits, and neglect of small and medium class savers.

CBN assessment of 2004 shows that while the overall health of the Nigerian banking system could be described as generally satisfactory, the state of some banks were less cheering. Specifically, as at end-March, 2004, the CBN's ratings of all the banks, classified 62 as sound/satisfactory, 14 as marginal and 11 as unsound, while 2 of the banks did not render any returns during the period. The weaknesses of some of the ailing banks were manifested by their overdrawn positions with the CBN, high incidence of non-performing loans, capital deficiencies, weak management and poor corporate governance.

The poorly managed liberalization reform of the 1980s' is partly responsible for the sector's weaknesses mentioned above. Supervision remained weak and there was evidence that many banks had bad balance sheets, conducting only very limited lending to the private sector, while engaging in short term foreign exchange arbitrage. To strengthen the financial system and improve on the ending to the private sector; the consolidation exercise was launched in mid - 2004. The CBN required all deposit banks to raise their minimum capital base from about N2 billion to N25.0 billion by the end of 2005(Note 5). The banking sub-sector reform of 2005 was adjudged as most successful, with the emergent of 24 strong banks (down from 89), larger capital base (from under US $\$ 3.0$ billion to over US $\$ 9.0$ billion), rating of Nigerian banks by international rating agencies (S \& P; Fitch) for the first time, branch network increased from 3,200 in 2004 to 3,866 in April 2007. The 919 Community/Micro Finance Banks (capital requirement about US\$156,000) and 11 banks had market capitalization ranging between US\$1.0 billion and US\$5.3 billion (Soludo, 2007). 
Also, the insurance sector went through the process with only about 71 insurance companies sailing through. The industry is now recapitalized to the tune of over N200.0 billion from the pre-consolidation position of just N30 billion. These reforms were complemented by improved regulatory and oversight function by the Central Bank. The Bank started the process of migration from a prudential supervision system to a risk based approach within the framework of the Basel - II Accord. Various measures were similarly implemented to ensure a smooth liquidation of banks that failed to meet the capitalization requirements. Three important legislations (CBN/BOFI Act, NDIC Act and Microfinance Act) were submitted to the National Assembly to strengthen the Consolidation programme. The bills sought to improve the autonomy of the Central bank in its monetary policy decisions; comprehensive framework for addressing the case of private depositors, who may be affected by the liquidation process; and to support the development of the microfinance industry in Nigeria.

\subsubsection{Reforms}

Eight main interdependent factors are believed to have led to the creation of an extremely fragile financial system that was tipped into crisis by the global financial crisis and recession. These factors include; macro economic instability caused by large and sudden capital inflows; major failures in corporate governance at banks; lack of investor and consumer protection; inadequate disclosure and transparency about the financial position of banks; critical gaps in regulatory framework and regulations; uneven supervision and enforcement; unstructured governance and management process at the $\mathrm{CBN}$; and weaknesses in the business environment in the country.

The Central Bank of Nigeria (CBN) in response to the above problems, unveiled a ten-year reform blue print anchored on four cardinal reform programmes for the stabilization of the banking sector and the finance sector in general. The four cardinal programmes for the sector's transformation involves enhancing the quality of banks; establishing financial stability; enabling healthy financial sector evolution and ensuring that financial sector contributes to the real economy. The CBN plans to initiate a five part programme to enhance the operations and quality of banks in Nigeria, which would consist of industry remedial programmes to fix the key causes of the crisis, implementation of risk based supervision, reforms to regulations and regulatory framework, enhanced provision for consumer protection and internal transformation of the CBN(Note 6). It would also include the development of directional economic policy and counter-cyclical fiscal policies by the government and further development of capital markets as alternative to bank funding. Some of the potential levers for the new macro-prudential rules may include limiting capital market lending to a set proportion of bank's balance sheet, prohibiting banks from using depositors' funds for proprietary trading, private equity or venture capital investment, adjusting capital adequacy and forward looking capital requirement driven by stress tests by the CBN. Although, the financial system has undergone substantial changes over the last two decades, the system remains by and large unstable and under-developed, since it is yet to achieve that degree of financial intermediation, which the economy requires to foster growth and development.

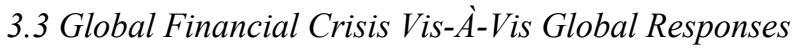

The major problem was arcane financial innovations like leveraging, swaps and sub-prime lending. These arcane financial instruments are so complicated that an investor needs an expert to explain how it works, due to mystery surrounding these instruments; they became handy tools for fraud in the financial system. Innocent investors were convinced by the rating agencies to buy instruments they barely understood. This caused a lot of litigation in American courts presently. Another problem was loose regulatory regimes and several unregulated financial markets and products. There were lots of regulatory forbearance on the part of the regulator of the financial system in the developed world, especially the United States, where Wall Street was behaving in a reckless manner at the expense of the investors, today the chicken has come home to roast, some of the big names in the Wall Street implicated in the crisis are either in jail or they have lost their jobs. Uncoordinated and late intervention by governments and Central Banks also helped in exacerbating the crisis, late intervention by President George Bush government in the wake of near financial collapse of Bear-Stern and its perfunctory intervention during the bankruptcy of Lehman Brothers worsened the crisis. Easy monetary policy in the aftermath of $9 / 11$ to avoid a recession, with high liquidity, investor and lender seek higher returns through riskier investments, false assumption of an ever increasing housing prices, leading to sub-prime mortgage lending, continued fall in house prices and borrowers inability to refinance, thus leading to defaults, while investment banks exposure through leveraging continued. With crash of structured products and mortgage market, consumer loans and mortgage market distress, led to counter-party risk, rising illiquidity crisis, which made the banks to stop lending and even recalled some of their loans, thereby exacerbating the financial instability. Stock market burst was also implicated; pressure on banks to raise capital brought undue pressure to the stock market causing huge write-downs and downgraded ratings. 
One of the major impact of the crisis on the global economy is the declining in real output growth, and threat of global recession, also weakened financial systems caused by the crisis, precipitated takeovers and bankruptcy, which in turn led to loss of jobs and loss confidence in financial markets, leading to inability of the financial houses to carry out their intermediation role in the economy. Ultimately this led to stock market crashes which deepened the liquidity and Credit crunch, thus crushing confidence and consumer demand in the economy. It also brought about sub-prime crisis of 2007 and breakdown of confidence in the banking system. Another impact the crisis had on global economy was de-leveraging and banks inability to improve capital adequacy and possible protracted recession in the US and Europe, with upturn expected perhaps in late 2010 and 2011. The responses to the crisis by the central banks around the world have been swift. They came in form of coordinated interest rate cuts and liquidity injections in G-8 countries and emerging markets. These injections were done in investment banks and other financial institutions like insurance companies. Governments also provided lending guarantees to restore liquidity, and revive the ailing banking system through recapitalization and strengthening of supervision, bank deposit guarantees and minimization of market disruptions through crackdown on short selling. The governments around the globe also injected trillions of dollars into the world economy to stimulate aggregate demand, the government in furtherance of it stimulus package subsided to ailing sectors in their various economies.

\subsubsection{Impact on the Nigerian Economy}

The main impact of the crisis on the Nigerian economy was the collapse of commodity prices, especially the fall in oil revenue, reducing the government ability to carry out some its financial obligations. Also, the declining capital inflow in the economy vis-à-vis de-accumulation of foreign reserves and attendant pressure on Nigerian exchange rate was another impact. There has been also limited foreign trade finance by banks due to low liquidity and dry-up of credit line. Foreign investors fled Nigerian capital market in droves, causing huge downturn in the capital market. This divestment brought about tightness and possible second round effects on the balance sheet of banks by increasing provision for bad debt and decrease in profitability.

A presidential Steering Committee on Global Economic Crisis was set up in January 16, 2009 to look into the crisis and proffer how the country will ameliorate the unpleasant effect on the Nigerian populace. The government previously set up a Presidential Advisory Team on capital market in August, 2008 to deliberate on measures to reverse the declining fortunes of the Nigerian Capital Market. The Security and Exchange Commission (NSC) and other capital market stakeholders reduced their fees by 50.0 per cent. NSC also reviewed trading rules and regulations. 1.0 per cent maximum downward limit on daily price movement and 5.0 per cent on upward movement, and this has been harmonized to 5.0 per cent either way from end-October 2008 . On the other hand, the CBN complimented the efforts of NSC by reducing the Monetary Policy Rate (MPR) from 10.25 per cent to 9.25 percent, the Bank also reduced Cash Reserve Requirement (CRR) from 4.0 per cent to 2.0 per cent, reduction of liquidity ration from 40.0 per cent to 30.0 per cent. Banks were also directed to restructure their margin loan up to 2009. Lending facilities to banks by the CBN were expanded up to 360 days. Expanded Discount Widow (EDW) facility was also introduced and liquidity mopping-up since September 2008. However, the Bank has discontinued with the EDW operations, and guaranteed all the loans within the inter-transactions at the money market.

\section{Lessons of Macroeconomic and Financial Stability}

The financial crises in the 1990s; starting with the Mexican crisis in 1994-95, followed by the Asian financial crisis in 1997-98 and the crises in Russia and Brazil, have provided a wealth of experience from which to draw lessons. Howbeit, the recent global financial crisis exposed the deep weakness of the financial sector. Much of the experience over the past decade highlights the critical importance of establishing fiscal and monetary control as the bedrock of macroeconomic stability. Fiscal and monetary control, in turn, ultimately rest on containing public sector financial imbalances, including quasi-fiscal lending through the financial system. Quasi-fiscal activities can become major threats to securing and maintaining monetary control.

Quasi-fiscal lending is the first pillar of fiscal and monetary control. Using the banking system to subsidize real activities undermines the development of a credit culture and has long been established as a key source of banking unsoundness. Soft loans to the agricultural sector in Turkey and to large state enterprises in Russia, for example, were major sources of financial fragility in both countries in the run-up to their financial crises. Moreover, quasi-fiscal lending undermines the integrity of public financial flows and stocks, which may be burdened by contingent liabilities from the financial system that are difficult to quantify. Similarly, the difficulty of distinguishing between commercial and soft loans impairs the quality of banking indicators, which may consequently underestimate the depth of asset quality problems. 
A second pillar of fiscal and monetary control is to clearly define the State's role in the financial system. The State plays a vital role in preserving financial stability by containing moral hazard through prudential regulation and supervision and by protecting depositors through a safety net, including deposit insurance and central bank emergency lending. In doing so, however, it is critical to draw a line in the sand. The potential scale, scope, and duration of the State's financial guarantees - for example, on the types of financial institutions and classes of liabilities that will be protected-ought to be spelled out in advance. Making explicit the extent of the State's support for the financial system can reduce moral hazard in the economy, so long as it is credible.

A third pillar - and an essential prerequisite - of fiscal and monetary control is reliable and timely information on the financial and non-financial sectors. Decision-makers in central banks, supervisory agencies, and finance ministries need adequate financial information to monitor and diagnose financial sector problems, and to distinguish between illiquidity and insolvency of individual institutions.

A fourth pillar is the specific rules on accessing central bank credit facilities that are well-defined, clearly articulated and publicized, and consistently applied. This principle applies to all types of central bank credits provided in the course of regular monetary operations or extended to the government, other public authorities or private companies, either on a regular or emergency basis.

A fifth pillar is for central bank to have clear lines of responsibility and accountability. There is now considerable evidence that suggests that central bank operational autonomy plays an important role in financial stability.

It has now been generally agreed that the first step in launching a financial restructuring program is to undertake a diagnostic review of financial institutions to assess their true condition, separate viable versus nonviable institutions, and identify candidates for restructuring. On the basis of the financial sector assessment, the authorities must then develop a comprehensive reform strategy that includes:

(1) Long-term vision for the financial sector, including its size, institutional composition, and ownership structure;

(2) A commitment and timetable for privatization, including after banks have been taken over by the government following a crisis; and

(3) Coordinates banking and fiscal reforms. Pursuing fiscal reforms and financial sector reforms simultaneously is particularly important for a country like Nigeria, where the scale and scope of both public finance and bank restructuring are large and highly interdependent. On the basis of the reform strategy, the institutional framework and incentives need to be strengthened to achieve reform objectives.

This involves several elements:

- An out-of-court mechanism for corporate debt restructuring should be established to help restore debt-repayment capacity among viable firms and to recover Non Performing Loans. Recourse to informal mechanisms often becomes necessary during large-scale restructuring because formal insolvency procedures are often too cumbersome and judicial systems have limited capacity to process a large number of cases.

- In order for out-of-court mechanisms to work, they need to be backed up by a supporting legal framework, which clearly defines the rights and obligations of creditors and debtors.

- Adequate prudential regulation and supervision consistent with international best practice. Particularly important is the implementation of a loan classification and general portfolio review system to allow regulators to detect trouble early on and take prompt corrective actions, where necessary. Prudential regulations also need to ensure an appropriate level of disclosure to protect depositors and investors and to enable the exercise of market discipline.

\section{Issues, Challenges and Prospects}

The Nigerian financial system is vulnerable to a number of risks, and there are serious concerns about the soundness and stability of the banking system. The Nigerian anti-money-laundering (AML) legal framework and enforcement is also considered inadequate, making the system vulnerable to financial abuse. Inefficiencies, such as delays and backlogs, in administration of justice by courts are also major impediments to the smooth functioning of the financial system.

On the part of banks, the challenges are enormous. We recognize that banks and their owners are primarily in business to make profit, and we are conscious of the need not to jeopardize this key driving motivation for innovation and entrepreneurship. However, we all know that banking system occupies a unique position in every 
economy and that is why it often attracts more than a casual regulatory attention. Our industry in the 21 st century must have a moral face and live up to some modicum of social responsibility. Capitalism must have a social face and a human soul to be sustainable. This is the lesson of world history. It is in this context that we view with serious concern the spate of frauds, ethical misconduct, falsification of returns by the banks to the Central Bank, unprofessional use of female staff in some banks in the name of 'marketing' and 'sourcing of funds', etc. Collectively, we can stop these misconducts and give the system a new face.

One of the most central economic policy challenges is to strike a balance between stability and reform in the financial sector. Clearly, there is no single "right" place on this continuum. Ultimately, the issue is about balancing the economic, financial, and social costs in the short term to medium term with potential gains in the long term. Allowing problems in the financial sector to fester may preserve stability in the short run, but could lead to pronounced distress and higher costs later on. At a minimum, sufficient progress has to be made to avoid deepening existing vulnerabilities, while building the capacity to manage financial distress when and if it occurs in the future.

Secondly, a key challenge will be to develop a credit culture. With the stock of non-performing loans already high, it is crucial to avoid a further build-up. This goal is interdependent with developing a credit culture and with improvements in corporate governance and sustaining economic growth. Fostering a credit culture and better governance, in turn, hinge on a reliable legal framework, supportive of private sector activity.

Thirdly, a closely related task is to resolve the stock of distressed debt in the economy. In essence, distressed debt is the counterpart to a portion of the capital stock and enterprises that need to be restructured or written off and closed. Once these restructurings and write-offs take place, resources - currently locked up would be freed up to finance new investment and consumption opportunities.

Fourthly, in the longer term, the financial sector needs to adapt to a new economic environment. The Nigerian economy is becoming increasingly market-oriented and opening up to foreign competition amongst others. The financial sector in particular may have to compete for creditworthy borrowers and skilled banking personnel. As flexibility is introduced into the exchange and interest rates over time, financial institutions would have to become adept at pricing credit risks and managing market risks.

Fifthly, another long term challenge is to deepen capital markets in order to diversify the sources of investment financing. Greater equity financing can help transform the ownership structure of the economy, attract strategic investors capable of restructuring their firms, and bolster market discipline. As with bank lending, the efficiency of equity financing would be a function of the quality of investment decisions made by investors and their ability to monitor and manage firms under their ownership through effective accounting, disclosure, and governance standards. Capital markets would also provide opportunities for risk diversification by investors, whose savings are still primarily invested in low-yielding bank deposits or in shares on the relatively undeveloped stock market.

\section{Summary and Recommendations}

Howbeit, the financial system in Nigeria still remains fragile and vulnerable to several external risks, including (i) the economy's high dependence on volatile oil proceeds; (ii) economic mismanagement, in particular fiscal imprudence; and (iii) political uncertainty. Given the large size and role of the government in economic activity and its virtual monopoly over the country's export earnings, fiscal indiscipline is the single most important threat to the economy and the financial sector today. Adopting a prudent, medium term oriented fiscal policy and introducing more market-based mechanisms in the foreign exchange market and the domestic money market would help to reduce vulnerabilities, remove distortions, and, hence, improve the efficiency of the financial system.

In managing financial crises, bank restructuring is an essential prerequisite for, but also highly dependent on macroeconomic stabilization. Given their interdependence, restructuring and stabilization need to be pursued in parallel (Note7). The formulation and implementation of a credible and comprehensive stabilization and structural reform program are also needed for stable prices, interest rates, and exchange rates, which are prerequisites for market participants to value firms and assets, and execute transactions. Even where a full-blown financial crisis has not occurred, as was the case in many transition economies, relative price changes, including the transition to market-based interest rates, must be effected before bank restructuring can begin in earnest; otherwise firms and collateral become impossible to value. Much of the experience over the past decade highlights the critical importance of establishing fiscal and monetary control as the bedrock of macroeconomic stability (Stefan Ingves; 2002) (Note8). 
In analyzing the effects of financial sector reforms, it is often useful to appraise the fiscal process. Fiscal stability and the success of monetary reforms are interrelated. Without fiscal balance, the resulting increased budgetary expenditure could motivate authorities to resort to larger deficit (perhaps, financed through money creation), which is capable of undermining the gains from the reform (Note 9) These developments could shift the burden of adjustment to the real sector (Johnston 1994). Also, depending on its nature, the fiscal process could contribute to higher rate of inflation and where the expansion in credit that follows liberalization is rapid and greater than deposit growth, this could lead to a loss of macroeconomic control, further causing and exacerbating the rate of inflation (Bisat, Johnston, and Sundararajan 1992). This process could spirally cause large increases in interest rates and prices and adversely affect the real sector. The fiscal stance as well as the behavior of the price level (i.e., the rate of inflation) is therefore important variables in assessing the outcome of financial reform.

Recent developments in the banking sector, including increased signs and incidence of distress, are a cause for serious concern and call for decisive and expeditious actions to safeguard the stability and soundness of the banking system. The banking system is likely to worsen if economic performance deteriorates (Onwioduokit, 2006). Hence, further banking system distress, including a systemic problem in the banking sector, cannot be confidently ruled out. The banking system continues to be characterized by (i) weak corporate governance; (ii) widespread insider lending; (iii) dependence on the government for business; (iv) high levels of non-performing loans and systematic under-provisioning; (v) persistent misreporting by many banks, which prevents detecting of emerging problems and precludes an accurate, risk-based analysis; and (vi) a high reliance on direct controls for prudential and liquidity management purposes, which has not only kept supervisors from making careful risk assessment of the industry, but has also stretched thin valuable.

Banks are expected to imbibe best-practice, corporate governance, improve on self-regulation, enhance the capital base, institute IT-driven culture, and seek to be competitive in today's globalizing world. Diversification of the productive base of the economy remains a fundamental challenge of economic management, and banks will increasingly be challenged to become more innovative in their intermediation function, and especially to increase financing to the productive sectors. The regulatory authorities, on their part, should further streamline the regulatory framework and strengthen the supervisory capacity to ensure a sound and efficient system (Note 10)

Financial stability also depends on policy credibility, founded upon a reliable judicial system, transparency, and well-defined institutional responsibilities. Strong and reliable legal and regulatory frameworks are the foundations upon which policy credibility and financial stability rest. In their absence, economic and financial policies can not be implemented. Legal and regulatory enforcement is needed to ensure action is taken against those that violate their prudential and financial obligations, and to act as a credible deterrent for all market participants (Note 11) The international community's efforts to prevent future financial crises - through reforms such as the development of international codes and standards - are built partly on a commitment to greater transparency. There is a consensus that openness in economic policymaking and in disseminating data on economic and financial developments is a key component of reform programs designed to strengthen economic fundamentals.

Capital account liberalization and financial sector restructuring and market development should be managed in an integrated, coordinated, and well-sequenced fashion. Permitting and attracting foreign direct investment into the financial services industry could serve as a catalyst for bank restructuring through the transfer of know-how and technology and by intensifying competition. Similarly, liberalizing portfolio flows over time can help deepen capital markets and strengthen the role of market discipline in the economy, provided that supporting prudential measures are adopted to contain greater foreign exchange risks associated with a higher volume of capital flows (Stefan Ingves; 2002). Howbeit, improper sequencing in the initial financial reforms led to crisis and eventual collapse of the financial system, necessitating several policy framework reversals in Nigeria. The crisis made policy consistency and credibility critical issues. Nonetheless, Nigeria's difficulty in sustaining a consistent policy stance was partly attributable to unstable general economic and political conditions. However, the failure of financial liberalization in Nigeria is largely to the political and institutional setting of reforms.

The paper postulates that the major constraints to successful financial reforms in Nigeria are inappropriate sequencing, inconsistency in policy mix, inadequate regulation and supervision. The role of the State should be viewed in a pragmatic manner taking into account the institutional and other aspects in designing and sequencing reforms as not all interventions are likely to be adverse. In summary, the Regulatory Institutions in Nigeria should amongst others implement:

i. Strong measures to better control insider lending; 
ii. A zero tolerance policy for the misreporting, under provisioning and violation of existing rules;

iii. Risk-weighted capital adequacy requirements;

iv. Less of open liquidity assistance to distressed banks; and

v. Reduction of reliance on direct monetary controls (i.e., high liquid asses ratios) in managing liquidity in the financial system in favour of indirect instruments, such as open market operations, and strengthen monitoring of prudential limits such as net open foreign exchange exposures for risk assessment.

Further research is required not only in investigating the relationship between financial fragility and overall growth in the country but also in refining the measures of financial development(Note 12)

\section{References}

Bisat, A., Johnston, R., and Sundararajan, V. (1992). Issues in Managing and Sequencing Financial Sector Reforms: Lessons from Experiences in Five Developing Countries. International Monetary Fund, Working paper, WP/92/82,

Callier P. (1991). Financial Systems and Development in Africa. Economic Development Institute of the World Bank, Washington D.C., World Bank

Diamond, Douglas W., and Philip H. Dybvig. (1983). Bank Runs, Deposit Insurance, and Liquidity. Journal of Political Economy, Vol. 91 (June), pp. 401-19.

Emenuga, C. (1996). Distortions in the Nigerian Financial Markets. In A. Ekpo (ed.), Fiscal and Monetary Policies During Structural adjustment in Nigeria, Proceedings of Senior Policy Seminar, held at the Central Bank of Nigeria, Lagos, March 6-7

Erdal, G, Okan, V.S and behiye, T. (2007). Financial Development and Growth: Evidence from Nothern Cyprus. International Research journal of Finance and Economics, issue 8.

Fisher, Irving. (1933). The Debt-Deflation Theory of Great Depressions. Econometrica, Vol. 1 (October), pp. $337-57$.

Goldsmith R. W. (1969). Financial Structure and Development. Yale University Press, New Haven.

Inanga E.L. (1995. Financial Sector Reforms in Sub-Sahara Africa. Paper Presented at the XI World Congress of the International Economic Association in Tunis on December 18-22

International Monetary Fund (IMF). (2002). Nigeria, Staff Report for the 2002 Article IV Consultation

Johnston, R. (1994). The Speed of Financial Sector Reform: Risks and Strategies. International Monetary Fund, IMF Paper on Policy Analysis and Assessment.

King R., and R. Levine. (1993). Finance, Entrepreneurship, and Growth. Paper presented at World Bank Conference on "How Do National Policies Affect Long-term Growth", Washington D.C.,

Leite, S.P., and V. Sundararajan. (1990). Issues on interest rate management and liberalization. IMF Working Paper, WP/90/12, IMF (March).

McKinnon R. (1973). Money and Capital in Economic Development. Washington D.C., Brookings Institution,

Mwega F. M., N. Mwangi and S.M. Ngola. (1990). Real Interest Rates and the Mobilization of Private Savings in Africa: A Case Study of Kenya. AERC Research Paper 2.

Obadan, M. I. (2004). Foreign Capital Flows and External Debt: Perspectives on Nigeria and the LDCs Group. Lagos-Nigeria: Broadway Press Limited.

Onwioduokit, Emmanuel A. (2006). Financial Liberation and Saving Mobilization in Nigeria. Vol. 30 1, Pg. 52 62, CBN Bullion.

Owen E, Alfredo M, Mahinder G, Paul H, Winfrid B, Russell K \& Marina M. (2000). Macroprudential Indicators of Financial System Soundness. IMF Occasional Paper 192

Patrick, H.T. (1966). Financial Development and Economic Growth in Underdeveloped Countries. Economic Development and Cultural Change, 14, 174-189.

Shaw, E. (1973). Financial Deepening in Economic Development. New York: Oxford University Press

Soludo, C. C. (2007). "Nigeria's Financial System Strategy 2020 Plan" Paper by the Governor, Central Bank of Nigeria at the FSS International Conference, Abuja-Nigeria, June 20. 
Soyibo A. (1994). Financial Liberalization and Bank Restructuring in Sub-Saharan Africa: Some Lessons for Sequencing and Policy Design. Paper Presented at an AERC Plenary, December, 1994.

Stefan I. (2002). Meeting the Challenges for the Chinese Financial Sector: What Have We Learned from Other Countries? Second China Financial Forum; Beijing, China, May 15-16, 2002.

Sylvanus I. Ikhide and Abayomi A. Alawode. (2001). Financial Sector Reforms, Macroeconomic Instability and the order of Economic Liberalization: The evidence from Nigeria. AERC Research Paper 112.

Turtleboom, B. (1991). Interest rate liberalization: Some lessons from Africa. IMF Working Paper, WP/ 91/121 (December).

Villanueva, D., and A. Mirakhor. (1990). Strategies for financial reforms. IMF Staff Papers, vol. 24. Washington, D.C.: IMF.

Wong, C.H. (1991). Market-based systems of monetary control in developing countries: Operating procedures and related issues. IMF Working Paper, WP/91/40. IMF: Washington, D.C.

World Bank. (1994). Adjustment in Africa: Reforms, Results and the Road Ahead, World Bank Policy Research Report, Oxford University Press, New York, 1994.

\section{Notes}

Note 1. Nigeria can be referred to as the financial supermarket in Africa

Note 2. Accordingly, the objective of financial reforms is to reduce or reverse this 'repression'

Note 3. The financial sector is involved in the mobilization of resources among savers and their allocation to borrowers as well as transformation and distribution of risks and maturities over time.

Note 4. Paper presented by the Banking Supervision Department at the Monetary Policy Department's retreat in Kaduna, January 30-31, 2009

Note 5. Implementation exercise triggered various mergers in the banking sector, reducing the number of deposit money banks to 25 from 89 , and eventually to 24 .

Note 6.The key features of this pillar would centre on strengthening the financial stability committee within the $\mathrm{CBN}$ and establishing a hybrid monetary policy and macro-prudential rules.

Note 7. The essential preconditions for fiscal and monetary control, including those outlined above, need to be met as soon as possible.

Note 8 . Fiscal and monetary control, in turn, ultimately rest on containing public sector financial imbalances, including quasi-fiscal lending through the financial system.

Note 9. Where the deficits are financed through market instruments, domestic interest rates could rise even in real rates, while exchange rate could appreciate.

Note 10. It is not enough to have a vision; it must be sequenced and integrated into economy wide analysis.

Note 11. Lack of transparency was a significant contributor to the emerging market crises in 1990s-especially to those in Nigeria, Mexico and Thailand, prompting a great deal of change since then.

Note 12. In general, we recommend that the authorities adopt a broad risk-focused framework for supervision, including a forward-looking risk assessment. 